\title{
Oligonucleotide Microarray Analysis of the SalA Regulon Controlling Phytotoxin Production by Pseudomonas syringae pv. syringae
}

\author{
Shi-En Lu, ${ }^{1}$ Nian Wang, ${ }^{1}$ Jianlin Wang, ${ }^{2}$ Z. Jeffrey Chen, ${ }^{2}$ and Dennis C. Gross ${ }^{1}$ \\ ${ }^{1}$ Department of Plant Pathology and Microbiology, Texas A\&M University; ${ }^{2}$ Department of Soil and Crop Sciences, Texas \\ A\&M University, College Station, TX 77843, U.S.A.
}

Submitted 12 October 2004. Accepted 22 November 2004.

The salA gene is a key regulatory element for syringomycin production by Pseudomonas syringae pv. syringae and encodes a member of the LuxR regulatory protein family. Previous studies revealed that salA, a member of the GacS/GacA signal transduction system, was required for bacterial virulence, syringomycin production, and expression of the syrB1 synthetase gene. To define the SalA regulon, the spotted oligonucleotide microarray was constructed using gene-specific 70-mer oligonucleotides of all open reading frames (ORFs) predicted in the syringomycin (syr) and syringopeptin (syp) gene clusters along with representative genes important to bacterial virulence, growth, and survival. The microarray containing 95 oligos was used to analyze transcriptional changes in a salA mutant (B301DSL07) and its wild-type strain, B301D. Expression of 16 genes was significantly higher ( $>$ twofold) in B301D than in the salA mutant; the maximum change in expression was 15-fold for some toxin biosynthesis genes. Except for the $s y l D$ synthetase gene for syringolin production, all ORFs controlled by SalA were located in the syr-syp genomic island and were associated with biosynthesis, secretion, and regulation of syringomycin and syringopeptin. The positive regulatory effect of SalA on transcription of $s y p A, \operatorname{syrB1}$, syrC, and $s y l D$ was verified by reporter fusions or real-time polymerase chain reaction analysis. None of the genes or ORFs was significantly down-regulated by the salA gene. These results demonstrated that a subgenomic oligonucleotide microarray is a powerful tool for defining the SalA regulon and its relationship to other genes important to plant pathogenesis.

Pseudomonas syringae pv. syringae causes cankers, blossom blights, and leaf spots in several economically important plants (Young 1991). A distinctive feature of this bacterium is the production of two lipopeptide toxins, syringomycin and syringopeptin (Bender et al. 1999), which are synthesized separately by modular nonribosomal peptide synthetases (Guenzi et al.

Corresponding author: D. C. Gross; E-mail: dgross@ppserver.tamu.edu; Telephone: 1.979.845.7313; Fax: 1.979.845.6483.

Current address of S.-E. Lu: Department of Entomology and Plant Pathology, Mississippi State University, Mississippi State, MS 39762, U.S.A.

* The $\boldsymbol{e}$-Xtra logo stands for "electronic extra" and indicates that Figures 1 and 2 are in color online and the HTML abstract available on-line contains a supplemental table of 70-mer oligonucleotide sequences not included in the print edition.
1998; Scholz-Schroeder et al. 2003; Zhang et al. 1995). The two phytotoxins are major virulence factors in plant pathogenesis (Scholz-Schroeder et al. 2001a).

Genes dedicated to biosynthesis, secretion, and regulation of the two toxins are localized in an approximately $150-\mathrm{kb}$ genomic island of the strain B301D chromosome. The syringomycin (syr) and syringopeptin (syp) gene clusters are located adjacent to one another on the chromosome and are approximately 55 and $90 \mathrm{~kb}$ in size, respectively (Lu et al. 2002; ScholzSchroeder et al. 2001b, 2003). The predominant feature of the toxin clusters is the presence of genes encoding modular nonribosomal peptide synthetases for syringomycin (i.e., syrB1 and $s y r E)$ and syringopeptin ( $s y p A, \operatorname{syp} B$, and $s y p C)$ production (Guenzi et al. 1998; Scholz-Schroeder et al. 2003; Zhang et al. 1995). Each peptide synthetase is composed of one or more catalytic modules responsible for the addition of a specific amino acid to the growing peptide chain (Mootz et al. 2002). As predicted from the toxin structures, nine syringomycin and 22 syringopeptin modules were identified and each module was shown to possess adenylation, thiolation, and condensation domains (Guenzi et al. 1998; Scholz-Schroeder et al. 2003; Zhang et al. 1995). A few regulatory genes, including the salA, syrF, and syrG genes, were identified within the syrsyp genomic island ( $\mathrm{Lu}$ et al. 2002). Functional salA and $s y r F$ genes are required for syringomycin production, and the syrG gene is not essential for toxin production but is associated with virulence of $P$. syringae pv. syringae. Three type I toxin efflux systems responsible for secretion of phytotoxins were predicted to occur within the syr-syp genomic island (Fig. 1) (Gross et al. 2003; Quigley et al. 1993). In addition, the flanking region of the right border of the syr-syp genomic island was sequenced and shown to encode a set of proteins sharing similarity to synthetases and a transporter of achromobactin (B728a genome, Joint Genome Institute) (Franza et al. 2002). The flanking region of the left border of the syr-syp genomic island also was sequenced and a few unknown open reading frames (ORFs) were predicted to be present (N. Wang and D. C. Gross, unpublished data). Altogether, a 180-kb genomic region containing the syr and syp genomic island was sequenced that encompassed approximately $3 \%$ of the genome of strain B301D.

Oligonucleotide microarray analysis is a powerful approach for studying transcriptional regulation (Rhodius and LaRossa 2003) and functional genomics (Giles and Kipling 2003; Kane et al. 2000; Lockhart et al. 1996; Tolstrup et al. 2003) and is applicable to studies of the regulatory network controlling expression of the syr-syp genomic island. DNA microarrays can be fabricated using genomic DNA (Gerhold et 
al. 1999; Okinaka et al. 2002), cDNA (Schena et al. 1995), polymerase chain reaction (PCR) products (de Souza et al. 2003; Richmond et al. 1999), and synthesized oligonucleotides (Giles and Kipling 2003; Kane et al. 2000; Lockhart et al. 1996; Tolstrup et al. 2003; Wagner et al. 2003). Transcriptional profiling by microarray analysis is increasingly being used in bacteria to define regulons (Britton et al. 2002; Cao et al. 2002; Laub et al. 2002; Schuster et al. 2003; Wagner et al. 2003) and stimulons (Price et al. 2001; Stewart et al. 2002; Zheng et al. 2001). For example, oligonucleotide microarray analysis was used by Wagner and associates (2003) to show that 626 genes were regulated by the quorumsensing system in Pseudomonas aeruginosa. Currently, oligonucleotide microarrays have become popular, due to their high gene specificity, uniform characteristics, and lower expense (Hessner et al. 2004); consequently, a growing number of 60- to 70-mer oligonucleotide microarrays are available commercially.

The salA regulatory gene was shown to have a critical role in syringomycin production and virulence of $P$. syringae pv. syringae. Consequently, the salA gene is an obvious focal point of transcription/microarray analysis of the syr-syp genomic island. The salA gene originally was identified from $P$. syringae pv. syringae B728a, a bean strain causing brown spot disease; salA was determined to be required for syringomycin production in vitro and lesion formation in bean leaves (Kitten et al. 1998). The GacS/GacA global signal transduction system positively regulates expression of the salA gene, and a functional salA gene is required for expression of the $s y r B 1$ synthetase gene of syringomycin (Kitten et al. 1998). A helix-turn-helix DNA-binding motif was identified from the $\mathrm{C}$ terminus of the putative SalA protein that exhibits significant homology to members of the LuxR regulatory proteins, such as GerE (Cutting and Mandelstam 1986) and DctR (Hamblin et al. 1993). Lu and associates (2002) demonstrated that the salA gene was localized $8.5 \mathrm{~kb}$ downstream of the $s y r E$ gene and that the putative SalA proteins from strains B301D and B728a differed by one amino acid. Furthermore, the salA gene was demonstrated to control expression of the $s y r F$ gene located between the $s y r E$ and salA genes (Fig. 1) and salA was associated with syringopeptin production (Lu et al. 2002).

Despite evidence that the salA gene is essential for syringomycin production and virulence of $P$. syringae pv. syringae, the members of the SalA regulon remain largely unknown. For example, it is unclear if the salA gene positively regulates ex- pression of all the genes associated with the syr-syp genomic island. In addition, multiple pathogenesis-related factors of $P$. syringae have been demonstrated or predicted to be involved in plant pathogenesis, such as the Hrp type III secretion system (Collmer et al. 2002), phytohormone synthesis (Glickmann et al. 1998; Mazzola and White 1994), siderophore production (Buell et al. 2003), syringolin production (Wäspi et al. 1998), and pectate lyase production (Bauer and Collmer 1997). It remains to be determined if the salA gene is involved in regulation of these pathogenesis-related factors.

In this study, a microarray was constructed of 70-mer oligonucleotides that represent all ORFs identified in the syr-syp genomic island, as well as genes involved in production of factors associated with plant pathogenesis. Transcriptional profiles of a salA mutant, B301DSL7 (salA::nptII) (Lu et al. 2002), were compared with those of wild-type strain B301D. Evidence is presented that the salA gene controls expression of genes contributing to the synthesis, secretion, and regulation of both syringomycin and syringopeptin phytotoxins, as well as the sylD synthetase gene for syringolin. These results are discussed in regard to the definition of the SalA regulon and its role in plant pathogenesis by $P$. syringae pv. syringae.

\section{RESULTS}

Construction of an oligonucleotide microarray.

A subgenomic microarray of $P$. syringae pv. syringae was constructed using 70-mer oligonucleotides that represent genes of interest. Of 95 oligonucleotides, 19 were designed from genes and putative ORFs identified from the $s y r$ gene cluster, and 30 oligonucleotides were selected from genes and putative ORFs located in the syp gene cluster or its border region (Fig. 1). In addition, oligonucleotides were designed for genes involved in the Hrp type III secretion system (avrP, virPphA, hrpL, hrpR, hrpS, hrpZ, hrpJ, hrpW, and hrpK), phytohormone synthesis (iaaM, iaaH, and efe), alginate production ( $\operatorname{alg} T$ and $\operatorname{alg} D)$, siderophore production ( $p v d S$, $p v d D$, $f s c, a c s D, c b r B, c b r D$, and fur), syringolin production ( $s y l D)$, ice nucleation (inaK), pectate lyase ( $p t l)$, environmental stress (rulA and $\operatorname{sodB}$ ), quorum sensing ( $a h l l)$, and global regulation ( $g a c S$, gacA, $r p o N, \operatorname{rpoS}, \operatorname{gyr} B$, and $\operatorname{sigX})$. All the oligonucleotides representing genes and ORFs identified in the syr-syp genomic island were designed from strain B301D of $P$. syringae pv. syringae. For large synthetase genes, more than one oligonucleotide were designed and included in the subgenomic microarray. Of the 95 oligonucleotides, 26 were

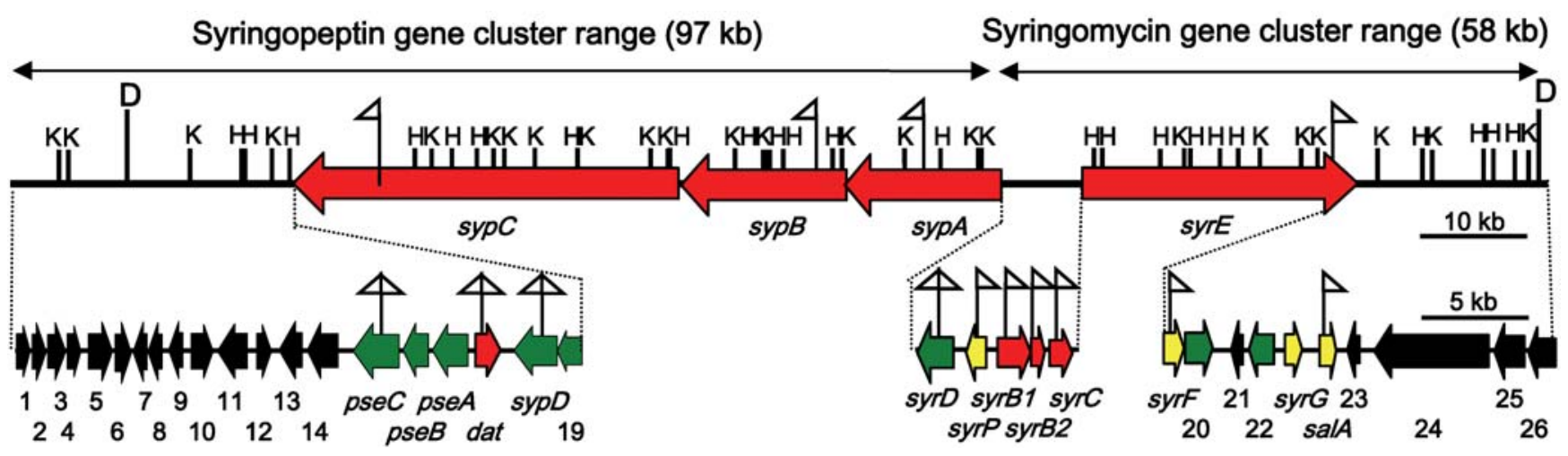

Fig. 1. A physical map of a 155-kb genomic DNA region of Pseudomonas syringae pv. syringae B301D containing both the syringomycin and syringopeptin gene clusters. The red, green, and yellow arrows represent genes that are predicted to be involved in, respectively, biosynthesis, secretion, and regulation of the phytotoxins. The black arrows represent genes whose functions remain unknown. The numbers identify the potential opening reading frames (ORFs). The phenotypic results of disruption of genes or ORFs are designated with a flag pointed right for loss of syringomycin production, a flag pointed left for loss of syringopeptin production, and a double-sided flag for loss of both syringomycin and syringopeptin production. The restriction enzyme sites for HindIII (H), KpnI (K), and DraI (D) are identified. 
selected from a genome sequence draft of $P$. syringae pv. syringae $\mathrm{B} 728 \mathrm{a}$, and 11 were from other strains of $P$. syringae pv. syringae. Oligonucleotides representing genes ptl (encoding pectate lyase; GenBank, AF219381) and efe (encoding ethylene biosynthetase; GenBank, AF101061) were designed from gene sequences identified from $P$. syringae pv. glycinea and $P$. syringae pv. pisi, respectively. In addition, oligonucleotides from various housekeeping genes $(\operatorname{gyr} B, \arg A, \arg E$, recA, and $16 \mathrm{~S}$ rDNA) were included as controls and for normalization. A random 70-mer oligonucleotide was synthesized and included as a negative control, which did not show homology to any region of the strain B728a genomic DNA sequence draft. The other negative control was designed from the luc gene encoding a firefly luciferase (GenBank, U47295). Melting temperature $\left(\mathrm{T}_{\mathrm{m}}\right)$ values of these oligonucleotides were averaged at $78.97^{\circ} \mathrm{C}(74.74$ to 81.77$)$.

Most features printed on the oligonucleotide microarray showed uniform and strong intensities of fluorescence when hybridized with sheared genomic DNA of strain B301D (data not shown). As expected, negative controls of the nucleotide representing the luciferase gene and the random oligonucleotide only produced the background noise as observed for the $3 \times \mathrm{SSC}$ buffer control ( $1 \times \mathrm{SSC}$ is $0.15 \mathrm{M} \mathrm{NaCl}$ plus $0.015 \mathrm{M}$ sodium citrate). In addition, four spots representing virPphA (Jackson et al. 1999), ptl (Bauer and Collmer 1997), avrP, and efe (Fukuda et al. 1992) showed signals that were comparable to the background level, suggesting the four genes may not be present in the B301D genome. Accordingly, the four gene fragments could not be detected using PCR amplification from the genomic DNA of strain B301D. Neither the ptl nor efe genes were identified from the genomic sequence draft of strain B728a.

\section{Overall transcriptional profiles}

of genes included in the subgenomic microarray.

All the genes dedicated to toxin production were expressed in the wild-type strain B301D at a high level when cultured on potato-dextrose agar (PDA) medium (Fig. 2; Table 1). Previous studies revealed that expression of a $\operatorname{syr} B 1:: l a c Z$ fusion in $P$. syringae pv. syringae BR132 reached a peak after a 3-day incubation on media conducive to toxin production (Mo and Gross 1991a and b). Consequently, total RNA was extracted from bacterial cells grown on PDA for $72 \mathrm{~h}$ and was used for transcriptome analysis. To estimate expression level of genes of interest, the background signal was calculated from the intensities of two negative controls, as well as from probes representing the virPphA, ptl, avrP, and efe genes that were not present in the B301D genome. Hybridization intensity analysis showed that signals of the syrBl and syrE synthetase genes for syringomycin production by strain B301D were observed to be 127 and 59 times higher than the background. Likewise, intensities of the other syr genes, including the $s y r B 2$, syrD, syrP, and syrC genes, averaged 52 times higher (ranging from 20 to 127) than the background. Signals from transcripts of the sypA, sypB, and sypC synthetase genes were 40, 44, and 17 times higher than the background, respectively. A few genes located outside the syr-syp genomic island expressed high levels (5 to 17 times higher that the recA gene) on PDA medium, such as $\operatorname{sig} X, \operatorname{alg} D, \operatorname{alg} T, \operatorname{sod} B$, and $\operatorname{ina} K$ (Fig. 2).

The most significant result of the oligonucleotide microarray analysis was the identification of genes that were positively regulated by the salA gene. To define the SalA regulon, the transcriptional profile of a salA mutant (B301DSL7) (Lu et al. 2002) was compared with the wild-type strain B301D. As observed in the scatter diagram shown in Figure 2, 20 spots rep-

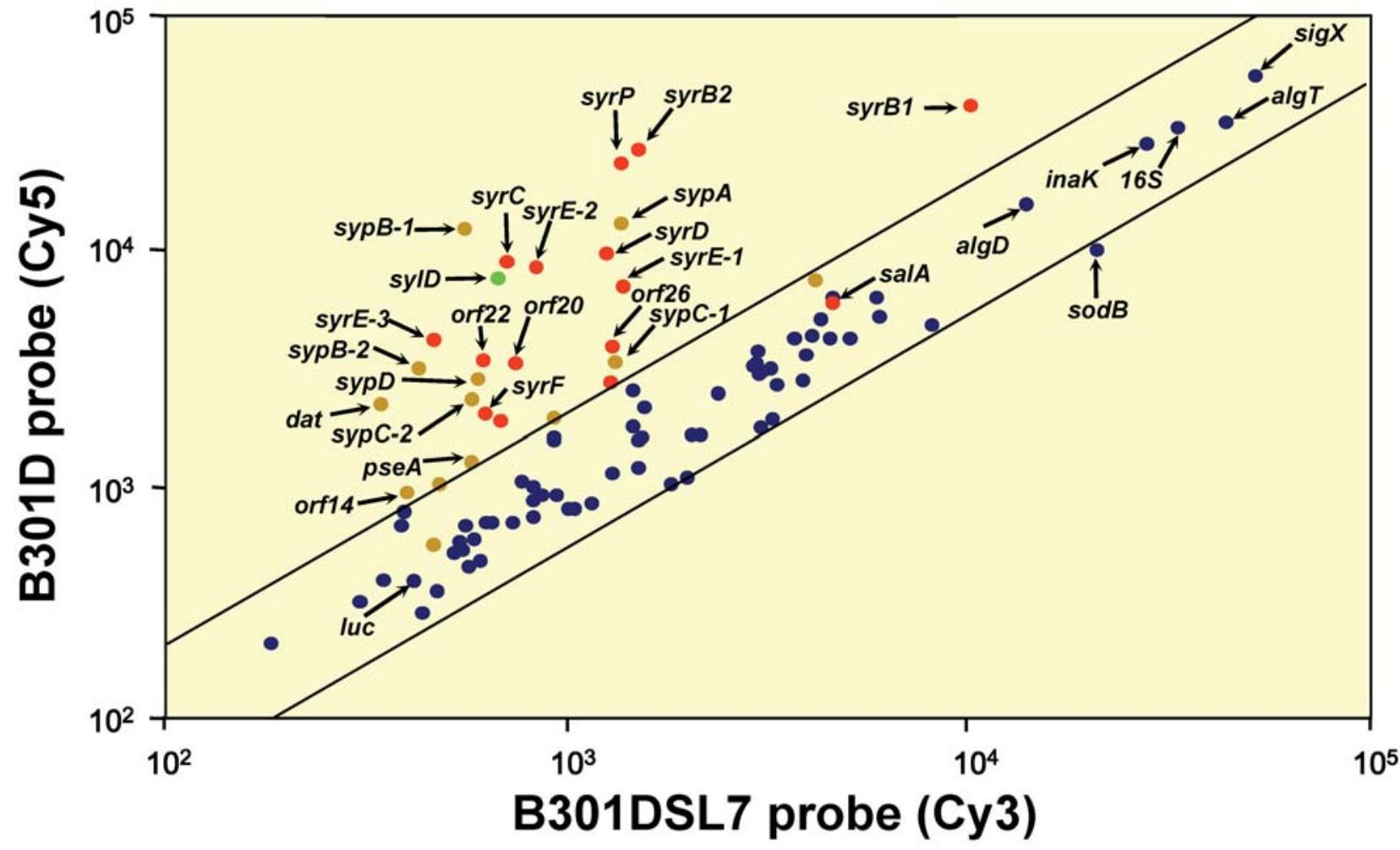

Fig. 2. Log plot of microarray signals obtained using B301D and B301DSL7 (salA) probes (cells grown on potato-dextrose agar for $72 \mathrm{~h}$ at $25^{\circ} \mathrm{C}$ ). Each spot on the array is represented by a dot in the scatter plot. The means of signal intensity of the B301D probe (Cy5) were plotted against those of the B301DSL7 probe $(\mathrm{Cy} 3)$. The top line represents a threshold $\mathrm{Cy} 5 / \mathrm{Cy} 3$ ratio of twofold and the bottom line shows a threshold $\mathrm{Cy} 5 / \mathrm{Cy} 3$ ratio of one-half. These data were derived from six replicates. The red and brown spots indicate expression profiles of genes associated with the syr and syp clusters, respectively. The syringolin biosynthesis gene $s y l D$ is identified by a green spot. Blue spots indicate genes associated with a variety of functions, including Hrp type III effectors and secretion, siderophore biosynthesis, alginate, phytohormone synthesis, and cellular housekeeping processes. 
resenting 16 arrayed genes were expressed significantly greater than twofold in strain B301D compared with that in strain B301DSL7; all, except for the sylD gene, were located within the syr-syp island. In this study, none of the genes or ORFs included in this array was observed to be negatively controlled by the salA gene. These results were consistently observed in dye-swap experiments.

\section{Effect of the salA mutation on transcription \\ of genes located in the syr-syp genomic island.}

Genes dedicated to biosynthesis, secretion, and regulation of syringomycin and syringopeptin were up-regulated by the salA gene. First, mutation in the salA gene resulted in significant reductions of transcripts for biosynthesis genes of syringomycin and syringopeptin, including the syrB1, syrB2, syrC, syrE, sypA, sypB, and sypC genes (Guenzi et al. 1998; ScholzSchroeder et al. 2003; Zhang et al. 1995) (Fig. 1; Table 1). All oligonucleotides designed from different locations in the same gene (e.g., syrE, sypB, or sypC) showed significant reductions in the salA mutant as compared with strain B301D, although the fold changes from the oligonucleotides of each gene were slightly different. Second, the transcriptional levels of genes involved in secretion of syringomycin and syringopeptin were significantly reduced in the salA mutant as compared with strain B301D, which include syrD (Quigley et al. 1993) and sypD (Gross et al. 2003). A similar effect of the salA mutation was observed on ORFs 20 and 22, which were predicted to encode an outer membrane protein and a cytoplasmic membrane protein, respectively (Lu et al. 2002). A resistance-nodulation-division (RND) transporter encoded by $p s e A, p s e B$, and pse $C$ was identified and was demonstrated to be associated with secretion of syringopeptin (Kang and Gross 2003). However, changes in transcriptional levels of pseA, pseB, and pseC were not significant between strains B301DSL7 and B301D under the conditions of this study. Third, a positive regulatory effect of salA was observed on $s y r F$ but not on $s y r G$, which corresponds to the results obtained using translational fusions to a uidA reporter gene (Lu et al. 2002). The syrP gene (Zhang et al. 1997) was expressed at a high level on the PDA medium and was reduced in transcription by about 20 times in the salA mutant. In addition, one ORF, named dat, located downstream of sypD (Fig. 1) was predicted to encode a protein with significant homology to aminotransferases (Ikai and Yamamoto 1997) involved in the formation of the modified amino acid, 2,4-diaminobutyric acid (D. C. Gross, unpublished data). Mutation in the salA gene resulted in a reduction of the transcriptional level of the dat gene by more than sixfold (Table 1). Similarly, transcription of ORFs 21 and 26 was decreased in the salA mutant, which shared similarity to cmaU (AlarcónChaidez et al. 1999) and mcpA (Kuroda et al. 1995), respectively. In contrast, transcription of some ORFs identified in the genomic island, such as ORFs 5, 6, 7, 23, 24, and 25, was not affected by a mutation in the salA gene (Table 1).

\section{Effect of the salA mutation on transcription}

\section{of genes located outside the syr-syp genomic island.}

No significant effect of the salA mutation was observed on genes located outside the syr-syp genomic island, except for the sylD gene (Table 1). The sylD gene encodes a nonribosomal peptide synthetase dedicated to biosynthesis of the syringolin peptide elicitor that induces resistance in rice plants (Amrein et al. 2004; Wäspi et al. 1998). Transcription of the sylD gene in a salA mutant (B301DSL7) was decreased by about eight times as compared to that in the wild-type strain B301D (Table 1). No significant effect of the salA mutation was observed on genes involved in the Hrp type III secretion system, phytohormone synthesis, alginate production, sidero- phore production, ice nucleation, environmental stress, or quorum sensing. It was observed that mutation in the salA gene did not affect transcription of any global regulators or sigma factors included in this study. A few genes not controlled by the salA regulon were highly expressed when cells were grown on PDA medium, which included genes associated with ice nucleation activity (inaK), alginate production $(\operatorname{alg} D, \operatorname{alg} T)$, and environmental stress (sodB) (Fig. 2).

Validation of microarray data.

Expression analysis of a sypA::uidA reporter strain of $P$. syringae pv. syringae confirmed positive regulation of the salA gene on transcription of the sypA synthetase gene of syringopeptin (Fig. 3). To evaluate expression of the sypA gene, reporter strain B301DSL29 was generated by forward insertion of a uidA-aaCCl fragment (Lu et al. 2002) into the sypA gene, generating a transcriptional fusion of the uidA gene to the $5^{\prime}$ end of the sypA gene. Recombination of the uidA-aacCl fragment into the chromosome of strain B301DSL29 was verified by Southern analysis. Strain B301DSL29 exhibited a high level of activity of $\beta$-glucuronidase (GUS) on PDA supplemented with 5-bromo-4-chloro-3-indolyl- $\beta$-D-glucuronide. To investigate the effect of the salA mutation on expression of the sypA::uidA reporter, the salA gene of strain B301DSL29 was disrupted by marker exchange of a salA::nptII construct (Lu et al. 2002) to generate strain B301DSL30 (sypA::uidA, salA::nptII). Southern analysis confirmed disruption of the salA gene in strain B301DSL20. As shown in Figure 3, strain B301DSL29 (sypA::uidA) exhibited high levels of GUS activity, averaging 410 units per $10^{8} \mathrm{CFU}$ after three days of incubation at $25^{\circ} \mathrm{C}$. In contrast, strains B301DSL30 (sypA::uidA, salA::nptII) and B301D did not produce GUS activity. This result verified the positive regulation of the salA gene on the syp $A$ synthetase gene of syringopeptin observed in microarray analysis.

The effect of the salA mutation on expression of $s y r C$, sylD, and $r e c A$ was validated by using real-time (RT)-PCR. Microarray analysis showed that transcriptional levels of $s y r C$, sylD, and $r e c A$ are 12.27-, 10.92-, and 0.88-fold higher, respectively, in the wild-type strain B301D than in the salA mutant (Table 1). RT-PCR analysis demonstrated that transcriptional levels of syrC and sylD were 11.6- and 9.0-fold higher, respectively, in strain B301D as compared with that in the salA mutant. As expected, no significant changes of the recA and inak transcriptional levels were observed between the mutant and wildtype strain from the RT-PCR analysis. These RT-PCR results agreed with the magnitudes of the changes determined from microarray analysis.

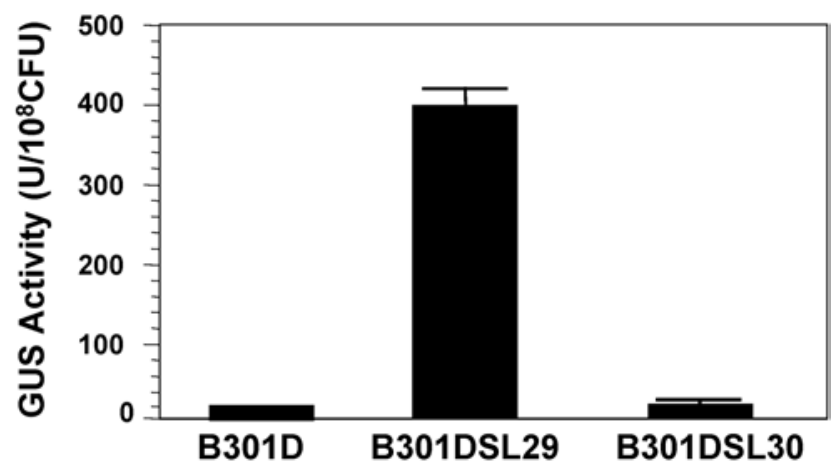

Fig. 3. The effect of mutation in the salA regulatory gene on expression of the sypA::uidA fusion. Strains B301D, B301D29 (sypA::uidA), and B301DSL30 (sypA::uidA; salA::nptII) were incubated for $72 \mathrm{~h}$ at $25^{\circ} \mathrm{C}$ in potato-dextrose broth medium. Vertical bars indicate standard error of the means for triplicate cultures. 


\section{DISCUSSION}

The results of this study demonstrated that the oligonucleotide-based subgenomic microarray is a powerful approach for gene expression profiling of virulence-associated genes in $P$. syringae. One of the earliest microarray studies of gene expression in a plant pathogenic bacterium was by Okinaka and associates (2002). They constructed a genomic DNA microarray containing random 3-kb clones of the Erwinia chrysanthemi 3937 genome and identified plant up- and down-regulated clones relative to growth on Luria-Bertani (LB) culture medium. However, limitations of the strategy were observed, including missing pathogenesis-related genes and over-represented clones (Okinaka et al. 2002). In contrast, the oligonucleotidebased microarray was demonstrated to have several advantages, such as gene specificity, enhanced flexibility in design, costeffectiveness, and uniformity (Denef et al. 2003; Hessner et al. 2004) as compared with a random DNA array. In this study, a subgenomic microarray system was successfully used to demonstrate that the SalA regulon controls expression of the syringomycin and syringopeptin gene clusters and that expression of other important virulence genes, such as those associated with Hrp type III secretion, are independent of SalA activity. As complete genome sequences of $P$. syringae strains become available, the 70-mer oligonucleotide microarray approach will be especially valuable to defining the complete set of genes composing a regulon such as that controlled by SalA, as influenced by changing environmental conditions.

Genes involved in biosynthesis, secretion, and regulation of syringomycin and syringopeptin are members of the SalA regulon. These genes are expressed at high levels on petri plates of PDA, a medium conducive to toxin production (Gross and DeVay 1977). With the exception of the sylD gene for syringolin, it appears that the genes positively regulated by the SalA protein are clustered in the syr-syp genomic island. The expression results obtained from microarray analysis indicate that the syr-syp genomic island consists of the DNA region extending from ORF14 to ORF26 (Fig. 1). Although it is possible that horizontal transfer of the syr-syp genomic island may occur in $P$. syringae strains, it is important to recognize that the syr-syp genomic island is not found in the genome of $P$. syringae pv. tomato DC3000 (Gross et al. 2003) and appears to not be present in several other pathovars of $P$. syringae (Quigley and Gross 1994).

Table 1. Microarray analysis of the SalA regulon

\begin{tabular}{|c|c|c|c|}
\hline Genes $^{\mathbf{a}}$ & Ratio $\left(\right.$ SEM) ${ }^{\mathbf{b}}$ & Gene product & References \\
\hline syrD & $7.47( \pm 1.78)$ & ATP-binding secretion protein & Quigley et al. 1993 \\
\hline syrP & $16.94( \pm 3.77)$ & Homologue of histidine kinase & Zhang et al 1997 \\
\hline syrB1 & $3.99( \pm 1.46)$ & Syringomycin synthetase & Zhang et al. 1995 \\
\hline syrB2 & $17.39( \pm 4.43)$ & Syringomycin biosynthesis enzyme & Zhang et al. 1995 \\
\hline $\operatorname{syrC}$ & $12.27( \pm 2.53)$ & Syringomycin biosynthesis enzyme & Zhang et al. 1995 \\
\hline syrE-1 & $9.90( \pm 2.97)$ & Syringomycin synthetase & Guenzi et al. 1998 \\
\hline syrE-2 & $5.17( \pm 0.72)$ & Syringomycin synthetase & Guenzi et al. 1998 \\
\hline syrE-3 & $7.85( \pm 0.97)$ & Syringomycin synthetase & Guenzi et al. 1998 \\
\hline syrF & $2.88( \pm 0.57)$ & LuxR family bacterial regulator & Lu et al. 2002 \\
\hline ORF20 & $4.32( \pm 0.84)$ & Putative outer membrane protein & Lu et al. 2002 \\
\hline ORF21 & $2.67( \pm 0.70)$ & Hypothetical protein & Lu et al. 2002 \\
\hline ORF22 & $5.34( \pm 1.77)$ & Membrane protein & Lu et al. 2002 \\
\hline $\operatorname{syr} G$ & $2.03( \pm 0.46)$ & LuxR family regulatory protein & Lu et al. 2002 \\
\hline salA & $1.35( \pm 0.16)$ & LuxR family regulatory protein & Lu et al. 2002 \\
\hline ORF23 & $0.55( \pm 0.17)$ & Hypothetical protein & Lu et al. 2002 \\
\hline ORF 24-1 & $0.91( \pm 0.23)$ & Hypothetical protein & Lu et al. 2002 \\
\hline ORF $24-2$ & $1.29( \pm 0.09)$ & Hypothetical protein & Lu et al. 2002 \\
\hline ORF 25 & $1.18( \pm 0.12)$ & Hypothetical protein & Lu et al. 2002 \\
\hline ORF26 & $2.94( \pm 0.47)$ & Unknown (chemotaxis protein) & Lu et al. 2002 \\
\hline sypA & $9.40( \pm 3.08)$ & Syringopeptin synthetase & Scholz-Schroeder et al. 2003 \\
\hline sypB-1 & $17.66( \pm 3.30)$ & Syringopeptin synthetase & Scholz-Schroeder et al. 2003 \\
\hline sypB-2 & $7.09( \pm 1.24)$ & Syringopeptin synthetase & Scholz-Schroeder et al. 2003 \\
\hline sypC1 & $2.58( \pm 0.40)$ & Syringopeptin synthetase & Scholz-Schroeder et al. 2003 \\
\hline sypC2 & $3.28( \pm 0.64)$ & Syringopeptin synthetase & Scholz-Schroeder et al. 2003 \\
\hline ORF19 & $1.74( \pm 0.27)$ & Putative membrane protein & Gross et al. 2003 \\
\hline sypD & $4.31( \pm 1.12)$ & Putative $\mathrm{ABC}$ transporter & Gross et al. 2003 \\
\hline dat & $6.22( \pm 1.14)$ & Aminotransferase & Gross, unpublished data \\
\hline pseA & $2.06( \pm 0.32)$ & Putative outer membrane protein & Kang and Gross 2003 \\
\hline pseB & $1.59( \pm 0.19)$ & Membrane fusion efflux protein & Kang and Gross 2003 \\
\hline pseC & $1.27( \pm 0.23)$ & Membrane fusion efflux protein & Kang and Gross 2003 \\
\hline ORF14 & $2.31( \pm 0.30)$ & Putative chemotaxis protein & N. Wang and D. C. Gross, unpublished data \\
\hline ORF13 & $2.14( \pm 0.34)$ & Unknown & N. Wang and D. C. Gross, unpublished data \\
\hline ORF12 & $0.81( \pm 0.14)$ & Sensor protein & N. Wang and D. C. Gross, unpublished data \\
\hline ORF11 & $0.94( \pm 0.15)$ & Amino acid deaminase & N. Wang and D. C. Gross, unpublished data \\
\hline ORF10 & $0.75( \pm 0.22)$ & Hypothetical protein & N. Wang and D. C. Gross, unpublished data \\
\hline ORF9 & $1.02( \pm 0.19)$ & Hypothetical protein & N. Wang and D. C. Gross, unpublished data \\
\hline ORF8 & $0.50( \pm 0.18)$ & Hypothetical protein & N. Wang and D. C. Gross, unpublished data \\
\hline ORF7 & $0.75( \pm 0.21)$ & Hypothetical protein & N. Wang and D. C. Gross, unpublished data \\
\hline ORF6 & $1.08( \pm 0.19)$ & Hypothetical protein & N. Wang and D. C. Gross, unpublished data \\
\hline ORF5 & $0.73( \pm 0.16)$ & Hypothetical protein & N. Wang and D. C. Gross, unpublished data \\
\hline ORF4 & $0.86( \pm 0.31)$ & Hypothetical protein & N. Wang and D. C. Gross, unpublished data \\
\hline ORF3 & $0.82( \pm 0.23)$ & Hypothetical protein & N. Wang and D. C. Gross, unpublished data \\
\hline ORF2 & $0.92( \pm 0.38)$ & Hypothetical protein & N. Wang and D. C. Gross, unpublished data \\
\hline ORF1 & $2.66( \pm 1.32)$ & Hypothetical protein & $\begin{array}{l}\text { N. Wang and D. C. Gross, unpublished data } \\
\text { Continued on next page }\end{array}$ \\
\hline
\end{tabular}

\footnotetext{
${ }^{a}$ The $p s y r$ numbers stand for ORFs predicted by www.jgi.doe.gov/JGI_microbial.

${ }^{\mathrm{b}}$ Data shown in the table are the means of six replicates of the three independent experiments with the standard errors of means (SEM).
} 
The salA gene encodes a key regulator for syringomycin production. Previous studies revealed that syringomycin production was eliminated in a salA mutant and that the salA gene positively controlled expression of the synthetase gene syrB1 and the regulatory gene $\operatorname{syr} F$ ( $\mathrm{Lu}$ et al. 2002). In this study, transcriptional levels of both the $s y r B 1$ and $s y r F$ genes in the salA mutant were significantly lower than those of the wildtype strain B301D, which is consistent with previous studies (Lu et al. 2002). In addition to syr genes, transcription of syp genes is positively regulated by salA. It was previously observed that mutation in the salA gene affected syringopeptin production based on phytotoxin bioassays (Lu et al. 2002). The results of this study suggest that the effect of the salA gene on syringopeptin production is via the positive regulation of salA on transcription of both synthetase genes (e.g., sypA, sypB, and $s y p C$ ) and secretion (e.g., sypD) genes. Expression of the pseA gene in strain B301D was twofold higher than that in the salA mutant; however, statistical analysis showed that the difference in expression level was not significant (Table 1). Further analyses are needed to investigate regulation of the salA gene on gene expression of the RND transporter system. It is not surprising that both syringomycin and syringopeptin are coregu- lated by SalA, because the two toxins contribute significantly to virulence of $P$. syringae pv. syringae (Scholz-Schroeder et al. 2001a).

The discovery that the syringolin biosynthesis gene sylD was controlled by the salA gene expanded the role of the SalA regulon in controlling expression of peptide metabolites important to the host-pathogen interaction. Syringolin was described by Dudler and associates (Hassa et al. 2000; Wäspi et al. 1998) as a peptide produced by $P$. syringae pv. syringae B301D that induced the hypersensitive response on nonhost plants including rice and wheat and was speculated to constitute a virulence factor. Recently, a gene cluster responsible for biosynthesis and secretion of the peptide was characterized and shown to be composed of four genes ( $s y l A, s y l B, s y l C$, and $s y l D$ ) (Amrein et al. 2004). It is speculated that the salA gene controls all genes essential for syringolin production. It has been frequently observed that one key regulator can control multiple genetic loci that might not be clustered physically (Hamon et al. 2004; Joyce et al. 2004; Martínez-Antonio and Collado-Vides 2003). For example, the hrpL gene was predicted to encode an alternative sigma factor (Xiao et al. 1994) and was localized to the $h r p / h r c$ gene cluster (Alfano et al. 2000). Interestingly, multiple

Table 1. Coniinued from preceding page

\begin{tabular}{|c|c|c|c|}
\hline Genes $^{a}$ & Ratio $(\text { SEM })^{\mathbf{b}}$ & Gene product & References \\
\hline hrpL & $1.18( \pm 0.14)$ & Alternative sigma factor & Alfano et al. 2000 \\
\hline hrpR & $1.03( \pm 0.10)$ & Regulatory factor & Xiao et al. 1994 \\
\hline hrpS & $0.84( \pm 0.38)$ & Positive regulatory factor & Xiao et al. 1994 \\
\hline hrpK & $1.16( \pm 0.09)$ & Unknown & N. Wang and D. C. Gross, unpublished data \\
\hline hrpJ & $0.56( \pm 0.15)$ & Flagellar biogenesis & Lidell and Hutcheson 1994 \\
\hline hrpZ & $1.09( \pm 0.12)$ & Harpin & He et al. 1993 \\
\hline hrpW & $0.77( \pm 0.08)$ & Type III effector & Charkowski et al. 1998 \\
\hline queA & $0.78( \pm 0.05)$ & Exchangeable effector locus & Alfano et al. 2000 \\
\hline EEl-chp & $1.04( \pm 0.22)$ & Type III chaperone protein & N. Wang and D. C. Gross, unpublished data \\
\hline hrmA & $0.96( \pm 0.17)$ & Avr (effector) proteins & Alfano et al. 2000 \\
\hline $\operatorname{gacS}$ & $1.06( \pm 0.11)$ & Sensor protein & Willis et al. 1990 \\
\hline gacA & $0.76( \pm 0.19)$ & Regulator protein & Rich et al. 1994 \\
\hline rpos & $1.01( \pm 0.17)$ & RNA polymerase sigma factor & Miller et al. 2001 \\
\hline rpoD & $0.91( \pm 0.14)$ & Principle sigma factor & Sawada et al. 1997 \\
\hline rpoN & $0.75( \pm 0.13)$ & Putative sigma- 54 protein & Alarcón-Chaidez and Bender 2001 \\
\hline $\operatorname{sig} X$ & $1.04( \pm 0.05)$ & Sigma factor & Brinkman et al. 1999 \\
\hline psyr020094 & $1.70( \pm 0.28)$ & Putative peptide synthetase & JGI-DOE microbial index \\
\hline psyr020651 & $0.84( \pm 0.12)$ & Putative peptide synthetase & JGI-DOE microbial index \\
\hline sylD & $10.92( \pm 2.69)$ & Putative syringolin synthetase & Amrein et al. 2004 \\
\hline algT & $0.78( \pm 0.07)$ & Alternative sigma factor & Keith and Bender 1999) \\
\hline $\operatorname{alg} D$ & $1.00( \pm 0.26)$ & GDP-mannose dehydrogenase & Fakhr et al. 1999 \\
\hline iaaM & $1.33( \pm 0.17)$ & Tryptophan monoxygenase & Mazzola and White 1994 \\
\hline$i a a H$ & $1.60( \pm 0.18)$ & Indoleacetamide hydrolase & Mazzola and White 1994 \\
\hline ahlI & $1.90( \pm 0.50)$ & Acyl homoserine lactone synthetase & Dumenyo et al. 1998 \\
\hline inaK & $0.90( \pm 0.16)$ & Ice nucleation protein & Jung et al. 1998 \\
\hline$p v d S$ & $1.32( \pm 0.14)$ & Putative acetylase & Mossialos et al. 2002 \\
\hline$p v d E$ & $1.01( \pm 0.04)$ & Pyoverdine synthetase & McMorran et al. 1996 \\
\hline fur & $0.89( \pm 0.10)$ & Ferric uptake regulator & Hassett et al. 1996 \\
\hline $\operatorname{lcc} C$ & $0.75( \pm 0.10)$ & Levansucrase & Li and Ullrich 2001 \\
\hline $\operatorname{cbr} B$ & $0.96( \pm 0.07)$ & Ferrisiderophore permease & Mahe et al. 1995 \\
\hline $\operatorname{cbrD}$ & $1.07( \pm 0.22)$ & ATP-binding unit in $\mathrm{ABC}$ transport & Mahe et al. 1995 \\
\hline$a c s D$ & $0.70( \pm 0.23)$ & Achromobactin biosynthetase & Franza et al. 2002 \\
\hline$f_{s c}$ & $0.94( \pm 0.12)$ & Ferric siderophore receptor & Nelson et al. 2002 \\
\hline SR-dat & $0.54( \pm 0.20)$ & Diaminobutyrate transaminase & Ikai and Yamamoto 1997 \\
\hline psyr020143 & $1.90( \pm 0.43)$ & Putative peptide synthetase & JGI-DOE microbial index \\
\hline tex & $1.01( \pm 0.09)$ & S1 RNA binding domain protein & Nelson et al. 2002 \\
\hline$g \operatorname{sh} A$ & $0.95( \pm 0.08)$ & Glutamate-cysteine ligase & Nelson et al. 2002 \\
\hline $\arg A$ & $0.76( \pm 0.10)$ & $\mathrm{N}$-acetylglutamate synthetase & Lu et al. 2003 \\
\hline $\arg E$ & $0.92( \pm 0.08)$ & Acetylornithine deacetylase & Lu et al. 2003 \\
\hline SA-ORFG & $1.06( \pm 0.07)$ & Unknown & Lu et al. 2003 \\
\hline rulA & $1.02( \pm 0.14)$ & Radiation tolerance & Sundin et al. 2000 \\
\hline $\operatorname{sod} B$ & $0.48( \pm 0.21)$ & Iron-superoxide dismutase & Hassett et al. 1993 \\
\hline $\operatorname{gyr} B$ & $1.00( \pm 0.07)$ & DNA gyrase subunit B & Sawada et al. 1997 \\
\hline recA & $0.88( \pm 0.11)$ & Principal sigma factor & Kokjohn and Miller 1985 \\
\hline luc & $1.02( \pm 0.36)$ & Luciferase & Coronado et al. 1994 \\
\hline negc10 & $0.96( \pm 0.17)$ & Random primer & Qiagen, Valencia, CA, U.S.A. \\
\hline $16 \mathrm{~S}$ rDNA & $1.00( \pm 0.07)$ & $16 \mathrm{~S}$ ribosomal RNA & Nelson et al. 2002 \\
\hline
\end{tabular}


hrpL-regulated genes encoding effectors were found scattered in the genome of $P$. syringae pv. tomato DC3000 (Buell et al. 2003; Fouts et al. 2002). Other virulence-associated genes may be present in the genome of $P$. syringae pv. syringae that belong to members of the SalA regulon. Recently, a draft sequence of the 6.08-megabase genome of $P$. syringae pv. syringae $\mathrm{B} 728 \mathrm{a}$ was assembled, and genome annotation is underway. The B728a genome project will allow the construction of a high-density oligonucleotide microarray that could be used for genomewide analysis of the SalA regulon of $P$. syringae pv. syringae.

Differences in ratios of expression for oligonucleotides representing different locations of the same gene were observed, although they were consistent in showing the same overall response due to salA mutation. For example, three oligonucleotides designed from different regions of the $s y r E$ gene showed 9.90-, 5.17-, and 7.85-fold changes in expression (Table 1). Similar results were observed for the $\operatorname{syp} B$ and $\operatorname{syp} C$ genes. Such variation was reported in a study by Wagner and associates (2003) and was attributed to RNA degradation. Alternatively, differences of expression levels observed from the oligonucleotides of one gene may result from the secondary structures of the mRNA flanking the oligonucleotides. For example, the effects of the secondary structures of regions flanking the oligonucleotides were detected in studies of single nucleotide polymorphisms using oligonucleotide microarrays (Anthony et al. 2003). It was suggested that the sequences used for identifying oligonucleotides were filtered with a 100-nt window across the target part of a gene to reduce effects of the flanking regions that have the potential to form stable secondary structures of cDNA (Tolstrup et al. 2003).

In conclusion, the SalA regulon plays an essential role in plant pathogenesis of $P$. syringae pv. syringae. Results of this study demonstrated that the SalA regulon is composed of genes associated with production of syringomycin, syringopeptin, and syringolin. An important observation is that all genes identified as part of the SalA regulon are absent from the genome of strain DC3000. Although the salA gene was reported to be present in strain DC3000 (Chatterjee et al. 2003), this is unlikely because the overall homology of the ORF (identified as PSPT02833) to the original SalA protein is low (less than $32 \%$ identity). Previous studies revealed that the salA gene was controlled by the GacS/GacA global regulatory system that controls multiple cellular functions associated with plant interactions (Kitten et al. 1998). Thus, results of this study provide evidence that the salA gene represents a vital junction in the $\mathrm{GacS} / \mathrm{GacA}$ regulatory system as it controls expression of genes essential for plant pathogenesis.

\section{MATERIALS AND METHODS}

\section{Bacterial growth conditions and RNA extraction.}

Strains of $P$. syringae pv. syringae were cultured with shaking at $25^{\circ} \mathrm{C}$ overnight in $5 \mathrm{ml}$ of potato-dextrose broth medium (Gross and DeVay 1977). To extract total RNA for analysis of gene transcription, cells were harvested by centrifugation and then diluted with sterile distilled water to a concentration of 2 $\times 10^{8} \mathrm{CFU} / \mathrm{ml}$. Cells from $50 \mu \mathrm{l}$ of the suspension, containing approximately $10^{6}$ cells, were plated on PDA containing $4 \%$ casamino acids (Gross and DeVay 1977), and the inoculated plates were incubated at $25^{\circ} \mathrm{C}$ for $72 \mathrm{~h}$. Bacterial total RNA was extracted, using a RiboPure bacteria kit (Ambion, Inc., Austin, TX, U.S.A.) as described by the manufacturer. Briefly, a pellet with $1 \times 10^{10}$ cells was suspended with $350 \mu \mathrm{l}$ of RNAwiz and then was lysed by vortex with zirconia beads. The lysate was then mixed with chloroform and the resulting mixture was centrifuged at $10,000 \times g$. RNA in the upper aqueous phase was recovered by $100 \%$ ethanol and bound to a silica filter. The RNA bound to the filter was washed to remove contaminants, and eluted with RNase-free water.

\section{Oligonucleotide design and synthesis.}

A set of 70-mer oligonucleotides representing the syr-syp genes of $P$. syringae pv. syringae and other genes of interest were designed and synthesized by Qiagen (Valencia, CA, U.S.A.). The oligonucleotides were selected based on the genome sequence draft of $P$. syringae pv. syringae B728a or on the genomic sequences of genes of $P$. syringae pv. syringae B301D or closely related strains of $P$. syringae. All oligonucleotides were selected using the following criteria: i) $T_{m}$ values of all oligonucleotides are within $\pm 5^{\circ} \mathrm{C}$; ii) each oligonucleotide is within 750 to 1,000 bases from the $3^{\prime}$ end of the available gene sequence; iii) each oligonucleotide is scanned for contiguous single nucleotide base repeats (less than seven bases) and hairpin stems (less than nine bases); iv) BLAST search to establish less than $70 \%$ identity to all other genes; and v) less than 20 contiguous repeats to any other gene in the genome sequence draft of strain B728a. The 70-mer oligonucleotides were synthesized at the $0.2 \mu \mathrm{mol}$ scale and were dispensed at 96-well plates.

\section{Microarray slide printing and blocking.}

Microarray slides were printed on poly-L-lysine-coated glass slides (CEL Associates, Inc. Pearland, TX, U.S.A.). The oligonucleotides were solubilized to a final concentration of $40 \mu \mathrm{M}$ with $3 \times$ SSC and were transferred into 96-well plates. All oligonucleotides were spotted in duplicate on one glass slide, using an OmniGrid 100 microarrayer (Genomic Solutions, Ann Arbor, MI, U.S.A.). Printing quality was checked using a microscope and scanner. Printed microarrays were fixed with a UV cross linker at $250 \mathrm{~mJ}$ and then were baked at $80^{\circ} \mathrm{C}$ for $3 \mathrm{~h}$. Blocking of microarray slides was performed using succinic anhydride as recommended by Qiagen. To further check the quality of the printed microarrays, two aliquots $(0.5 \mu \mathrm{g}$ per aliquot $)$ of the sheared genomic DNA (approximately $2 \mathrm{~kb}$ ) of strain B301D were labeled with Cy3 and Cy5, respectively, and were hybridized to the microarray to measure signal intensities as described below.

\section{Probe labeling.}

Procedures for probe labeling and oligonucleotide microarray hybridization were optimized as follows. Purified total RNA $(50 \mu \mathrm{g})$ was mixed with $3 \mu \mathrm{g}$ of random hexamers (Qiagen) and was incubated at $65^{\circ} \mathrm{C}$ for $10 \mathrm{~min}$. Reactions were held at room temperature for $10 \mathrm{~min}$ to allow the primers and the RNA template to anneal. To each reaction, the following were added: $2 \mu \mathrm{l}$ of Cy5/Cy3-dCTP $(1 \mathrm{mM})$ (Amersham Biosciences, Piscataway, NJ, U.S.A.), $3 \mu \mathrm{l}$ of $0.1 \mathrm{M}$ dithiothreitol, $6 \mu \mathrm{l}$ of $5 \times$ reverse transcriptase buffer, $2 \mu \mathrm{l}$ of dNTP mixture (15 mM dATP, dTTP, and dGTP; $5 \mathrm{mM} \mathrm{dCTP}$ ), and $200 \mathrm{U}$ of Superscript II reverse transcriptase (Invitrogen Corp., Carlsbad, CA, U.S.A.). The reactions were incubated at $42^{\circ} \mathrm{C}$ for $2 \mathrm{~h}$ in the dark. The RNA was hydrolyzed with $1.5 \mu \mathrm{l}$ of 1 $\mathrm{M} \mathrm{NaOH}$ at $65^{\circ} \mathrm{C}$ for $10 \mathrm{~min}$ and then was neutralized with 1 $\mathrm{M} \mathrm{HCl}$. A pair of $\mathrm{Cy} 5 / \mathrm{Cy} 3$-labeled probes was purified together with a PCR purification kit (Qiagen), and probes were eluted from filters with $30 \mu \mathrm{l}$ of sterile distilled water. The labeled probes (approximately $27 \mu \mathrm{l}$ ) were added to hybridization buffer containing $3 \times \mathrm{SSC}, 1 \%$ bovine serum albumin, and $0.25 \%$ sodium dodecyl sulfate (SDS). Probes were denatured at $95^{\circ} \mathrm{C}$ for $2 \mathrm{~min}$ and then were applied to slides. Hybridization was conducted in a moist chamber at $60^{\circ} \mathrm{C}$ for $14 \mathrm{~h}$. After hybridization, the slides were washed for $4 \mathrm{~min}$ in $2 \times \mathrm{SSC}$ and $0.1 \% \mathrm{SDS}$, for $4 \mathrm{~min}$ in $1 \times \mathrm{SSC}$ and $0.1 \% \mathrm{SDS}$, and for $4 \mathrm{~min}$ in $0.2 \times \mathrm{SSC}$. The slides were dried with centrifugation (10 
min, $1,000 \times g)$. The washed slides were scanned by using a GenePix 4000b (Axon Instruments Inc., Foster City, CA, U.S.A.) to visualize the hybridization images. The scanner PMT settings of two channels (532 nm for Cy3 and $635 \mathrm{~nm}$ for Cy 5 acquisition, respectively) were adjusted based on the ratio of $16 \mathrm{~S}$ rDNA expression (the $16 \mathrm{~S}$ RNA is expected to be equal between different strains). The 16S rRNA that was expressed to similar levels in both strains B301D and B301DSL7 based on RNA gel analysis was used to normalize the microarray expression data.

\section{Microarray data analysis.}

Signal intensity and ratios were obtained using GenePix Pro software provided with the scanner. Oligonucleotide spots with signals lower than 100 after subtracting background were flagged and eliminated for further analysis. The raw data were normalized with probe intensities of $16 \mathrm{~S}$ rRNA, which was transcribed to similar levels in both strains as a constitutively expressed gene. Hybridization experiments were performed in triplicate. Each slide contained duplicate arrays.

\section{Microarray validation \\ by RT-PCR analysis and GUS assays.}

Regulation of the salA gene on expression of $s y r C$ and $s y l D$ observed in microarray analysis was examined by qualitative real-time PCR using QuantiTect SYBR green RT-PCR kit (Qiagen). Primers used for RT-PCR were designed using the Lasergene expert sequence analysis package (DNAstar, Madison, WI, U.S.A.) according to primer criteria as described by Qiagen. The primers specific for 16S rRNA were generated for normalization controls. All primers used for RT-PCR are listed in Table 2. For each primer pair, the linearity of detection was confirmed to have a correlation coefficient of at least $0.98\left(r^{2}>\right.$ 0.98 ) over the detection area by measuring a fivefold dilution curve with RNA isolated from bacterial cells. An aliquot containing $100 \mathrm{ng}$ of total RNA as template was used for reverse transcription at $50^{\circ} \mathrm{C}$ for $30 \mathrm{~min}$, followed by initial activation of HotStar DNA polymerase $\left(95^{\circ} \mathrm{C}, 15 \mathrm{~min}\right)$. RT-PCR was performed in 40 cycles $\left(94^{\circ} \mathrm{C}\right.$ for $15 \mathrm{~s}, 55^{\circ} \mathrm{C}$ for $30 \mathrm{~s}$, and $72^{\circ} \mathrm{C}$ for $30 \mathrm{~s}$ ), followed by melting curve analysis as recommended for the RT-PCR kit of Qiagen to validate primer gene specificity.

Regulation of the salA gene on expression of the sypA gene was verified by GUS assays. A 3.2-kb uidA-aacC fragment of pSL02 (Lu et al. 2002) was cloned into pBS08 (ScholzSchroeder et al. 2001) at the BstZ17I site, to generate a transcriptional fusion of uidA to $\operatorname{syp} A$. The resulting construct was inserted into pBR325 at the EcoRI site previously blunted by T4 DNA polymerase to generate plasmid pSL200. A sypA::uidA reporter was constructed by introduction of pSL200 into $P$. syringae pv. syringae B301D to generate strain B301DSL29 by marker exchange mutagenesis. Similarly, pSL08 (Lu et al. 2002), which carries a disrupted salA gene by insertion of $n p t I I$, was used to generate strain B301DSL30 (sypA::uidA, salA::nptII) to evaluate the effect of mutation of

Table 2. Primers used for quantitative real-time PCR analysis

\begin{tabular}{lll}
\hline Name & \multicolumn{1}{c}{ Sequence } & \multicolumn{1}{c}{ Resource } \\
\hline syrCF & ACCTGCAAGCGATGTTCCTC & This study \\
SyrCR & TGCCAGCTCGGTCTTGTTCA & This study \\
sylDF & ACTATCGCGCTCGTGTCCAA & This study \\
syrDR & CAGCCCGATACCGTCAGAAA & This study \\
inaKF & CGGCGATAGAAGCAAACTC & This study \\
inaKR & GCCGGCCGTCAAGATACT & This study \\
recAF & CTTCGGTACGCCTGGACA & This study \\
recAR & AACTCGGCCTGACGGAAC & This study \\
16SF & ACACCGCCCGTCACACCA & Kang and Gross 2003 \\
16SR & GTTCCCCTACGGCTACCTT & Kang and Gross 2003 \\
\hline
\end{tabular}

salA on sypA expression. Homologous recombination in the resultant strains was verified by Southern analysis. GUS assays were performed as described by Lu and associates (2002).

\section{ACKNOWLEDGMENTS}

This work was supported in part by grant 2001-35319-10400 from the National Research Competitive Grants Program of the U.S. Department of Agriculture, Science, and Education Administration.

\section{LITERATURE CITED}

Alarcón-Chaidez, F. J., and Bender, C. L. 2001. Analysis of the rpoN locus in the plant pathogenic bacterium, Pseudomonas syringae pv. glycinea. DNA Seq. 12:77-84.

Alarcón-Chaidez, F. J., Penaloza-Vázquez, A., Ullrich, M., and Bender, C. L. 1999. Characterization of plasmids encoding the phytotoxin coronatine in Pseudomonas syringae. Plasmid 42:210-220.

Alfano, J. R., Charkowski, A. O., Deng, W. L., Badel, J. L., PetnickiOcwieja, T., van Dijk, K., and Collmer, A. 2000. The Pseudomonas syringae Hrp pathogenicity island has a tripartite mosaic structure composed of a cluster of type III secretion genes bounded by exchangeable effector and conserved effector loci that contribute to parasitic fitness and pathogenicity in plants. Proc. Natl. Acad. Sci. U.S.A 97:4856-4861.

Amrein, H., Makart, S., Granado, J., Shakya, R., Schneider-Pokorny, J., and Dudler, R. 2004. Functional analysis of genes involved in the synthesis of syringolin A by Pseudomonas syringae pv. syringae B301D-R. Mol. Plant-Microbe Interact. 17:90-97.

Anthony, R. M., Schuitema, A. R., Chan, A. B., Boender, P. J., Klatser, P. R., and Oskam, L. 2003. Effect of secondary structure on single nucleotide polymorphism detection with a porous microarray matrix: Implications for probe selection. Biotechniques 34:1082-1089.

Bauer, D. W., and Collmer, A. 1997. Molecular cloning, characterization, and mutagenesis of a pel gene from Pseudomonas syringae pv. lachyrmans encoding a member of the Erwinia chrysanthemi pelADE family of pectate lyases. Mol. Plant-Microbe Interact. 10:369-379.

Bender, C. L., Alarcón-Chaidez, F., and Gross, D. C. 1999. Pseudomonas syringae phytotoxins: Mode of action, regulation, and biosynthesis by peptide and polyketide synthetases. Microbiol. Mol. Biol. Rev. 63:266-292.

Brinkman, F. S., Schoofs, G., Hancock, R. E., and De Mot, R. 1999. Influence of a putative ECF sigma factor on expression of the major outer membrane protein, OprF, in Pseudomonas aeruginosa and Pseudomonas fluorescens. J. Bacteriol. 181:4746-4754.

Britton, R. A., Eichenberger, P., Gonzalez-Pastor, J. E., Fawcett, P., Monson, R., Losick, R., and Grossman, A. D. 2002. Genome-wide analysis of the stationary-phase sigma factor (sigma-H) regulon of $\mathrm{Ba}$ cillus subtilis. J. Bacteriol. 184:4881-4890.

Buell, C. R., Joardar, V., Lindeberg, M., Selengut, J., Paulsen, I. T., Gwinn, M. L., Dodson, R. J., Deboy, R. T., Durkin, A. S., Kolonay, J. F., Madupu, R., Daugherty, S., Brinkac, L., Beanan, M. J., Haft, D. H., Nelson, W. C., Davidsen, T., Zafar, N., Zhou, L. W., Liu, J., Yuan, Q. P., Khouri, H., Fedorova, N., Tran, B., Russell, D., Berry, K., Utterback, T., Van Aken, S. E., Feldblyum, T. V., D’Ascenzo, M., Deng, W. L., Ramos, A. R., Alfano, J. R., Cartinhour, S., Chatterjee, A. K., Delaney, T. P., Lazarowitz, S. G., Martin, G. B., Schneider, D. J., Tang, X. Y., Bender, C. L., White, O., Fraser, C. M., and Collmer, A. 2003. The complete genome sequence of the Arabidopsis and tomato pathogen Pseudomonas syringae pv. tomato DC3000. Proc. Natl. Acad. Sci. U.S.A 100:10181-10186.

Cao, M., Kobel, P. A., Morshedi, M. M., Wu, M. F., Paddon, C., and Helmann, J. D. 2002. Defining the Bacillus subtilis $\sigma^{\mathrm{W}}$ regulon: A comparative analysis of promoter consensus search, run-off transcription/macroarray analysis (ROMA), and transcriptional profiling approaches. J. Mol. Biol. 316:443-457.

Charkowski, A. O., Alfano, J. R., Preston, G., Yuan, J., He, S. Y., and Collmer, A. 1998. The Pseudomonas syringae pv. tomato HrpW protein has domains similar to harpins and pectate lyases and can elicit the plant hypersensitive response and bind to pectate. J. Bacteriol. 180:5211-5217.

Chatterjee, A., Cui, Y. Y., Yang, H. L., Collmer, A., Alfano, J. R., and Chatterjee, A. K. 2003. GacA, the response regulator of a two-component system, acts as a master regulator in Pseudomonas syringae pv. tomato DC3000 by controlling regulatory RNA, transcriptional activators, and alternate sigma factors. Mol. Plant-Microbe Interact. 16:1106-1117.

Collmer, A., Lindeberg, M., Petnicki-Ocwieja, T., Schneider, D. J., and Alfano, J. R. 2002. Genomic mining type III secretion system effectors in Pseudomonas syringae yields new picks for all TTSS prospectors. Trends Microbiol. 10:462-469. 
Coronado, C., Vazquez, M. E., Cebolla, A., and Palomares, A. J. 1994. Use of firefly luciferase gene for plasmid copy number determination. Plasmid 32:336-341.

Cutting, S., and Mandelstam, J. 1986. The nucleotide sequence and the transcription during sporulation of the gerE gene of Bacillus subtilis. J. Gen. Microbiol. 132( Pt 11):3013-3024.

de Souza, A. A., Takita, M. A., Coletta, H. D., Caldana, C., Goldman, G. H., Yanai, G. M., Muto, N. H., de Oliveira, R. C., Nunes, L. R., and Machado, M. A. 2003. Analysis of gene expression in two growth states of Xylella fastidiosa and its relationship with pathogenicity. Mol. PlantMicrobe Interact. 16:867-875.

Denef, V. J., Park, J., Rodrigues, J. L., Tsoi, T. V., Hashsham, S. A., and Tiedje, J. M. 2003. Validation of a more sensitive method for using spotted oligonucleotide DNA microarrays for functional genomics studies on bacterial communities. Environ. Microbiol. 5:933-943.

Dumenyo, C. K., Mukherjee, A., Chun, W., and Chatterjee, A. K. 1998. Genetic and physiological evidence for the production of $\mathrm{N}$-acyl homoserine lactones by Pseudomonas syringae pv. syringae and other fluorescent plant pathogenic Pseudomonas species. Eur. J. Plant Pathol. 104:569-582.

Fakhr, M. K., Penaloza-Vázquez, A., Chakrabarty, A. M., and Bender, C. L. 1999. Regulation of alginate biosynthesis in Pseudomonas syringae pv. syringae. J. Bacteriol. 181:3478-3485.

Fouts, D. E., Abramovitch, R. B., Alfano, J. R., Baldo, A. M., Buell, C. R., Cartinhour, S., Chatterjee, A. K., D’Ascenzo, M., Gwinn, M. L., Lazarowitz, S. G., Lin, N. C., Martin, G. B., Rehm, A. H., Schneider, D. J., van Dijk, K., Tang, X. Y., and Collmer, A. 2002. Genomewide identification of Pseudomonas syringae pv. tomato DC3000 promoters controlled by the HrpL alternative sigma factor. Proc. Natl. Acad. Sci. U.S.A 99:2275-2280.

Franza, T., Michaud-Soret, I., Piquerel, P., and Expert, D. 2002. Coupling of iron assimilation and pectinolysis in Erwinia chrysanthemi 3937. Mol. Plant-Microbe Interact. 15:1181-1191.

Fukuda, H., Ogawa, T., Ishihara, K., Fujii, T., Nagahama, K., Omata, T., Inoue, Y., Tanase, S., and Morino, Y. 1992. Molecular cloning in Escherichia coli, expression, and nucleotide sequence of the gene for the ethylene-forming enzyme of Pseudomonas syringae pv. phaseolicola PK2. Biochem. Biophys. Res. Commun. 188:826-832

Gerhold, D., Rushmore, T., and Caskey, C. T. 1999. DNA chips: Promising toys have become powerful tools. Trends Biochem. Sci. 24:168-173.

Giles, P. J., and Kipling, D. 2003. Normality of oligonucleotide microarray data and implications for parametric statistical analyses. Bioinformatics 19:2254-2262.

Glickmann, E., Gardan, L., Jacquet, S., Hussain, S., Elasri, M., Petit, A., and Dessaux, Y. 1998. Auxin production is a common feature of most pathovars of Pseudomonas syringae. Mol. Plant-Microbe Interact. 11:156-162.

Gross, D. C., and DeVay, J. E. 1977. Population dynamics and pathogenesis of Pseudomonas syringae in maize and cowpea in relation to in vitro production of syringomycin. Phytopathology 67:475-483.

Gross, D. C., Grgurina, I., Scholz-Schroeder, B. K., and Lu, S. E. 2003. Characterization of the syr-syp genomic island of Pseudomonas syringae pv. syringae strain B301D. Pages 137-145 in: Pseudomonas syringae and Related Pathogens. N. S. Iacobellis, ed. Kluwer Academic Publishers, Dordrecht, The Netherlands.

Guenzi, E., Galli, G., Grgurina, I., Gross, D. C., and Grandi, G. 1998 Characterization of the syringomycin synthetase gene cluster-A link between prokaryotic and eukaryotic peptide synthetases. J. Biol. Chem. 273:32857-32863.

Hamblin, M. J., Shaw, J. G., and Kelly, D. J. 1993. Sequence analysis and interposon mutagenesis of a sensor-kinase (DctS) and response-regulator (DctR) controlling synthesis of the high-affinity C4-dicarboxylate transport system in Rhodobacter capsulatus. Mol. Gen. Genet. 237:215-224

Hamon, M. A., Stanley, N. R., Britton, R. A., Grossman, A. D., and Lazazzera, B. A. 2004. Identification of AbrB-regulated genes involved in biofilm formation by Bacillus subtilis. Mol. Microbiol. 52:847-860.

Hassa, P., Granado, J., Freydl, E., Wäspi, U., and Dudler, R. 2000. Syringolin-mediated activation of the Pir7b esterase gene in rice cells is suppressed by phosphatase inhibitors. Mol. Plant-Microbe Interact. 13:342346

Hassett, D. J., Sokol, P. A., Howell, M. L., Ma, J. F., Schweizer, H. T., Ochsner, U., and Vasil, M. L. 1996. Ferric uptake regulator (Fur) mutants of Pseudomonas aeruginosa demonstrate defective siderophoremediated iron uptake, altered aerobic growth, and decreased superoxide dismutase and catalase activities. J. Bacteriol. 178:3996-4003.

Hassett, D. J., Woodruff, W. A., Wozniak, D. J., Vasil, M. L., Cohen, M. S., and Ohman, D. E. 1993. Cloning and characterization of the Pseudomonas aeruginosa sodA and $\operatorname{sodB}$ genes encoding manganese- and iron- cofactored superoxide dismutase: Demonstration of increased manganese superoxide dismutase activity in alginate-producing bacteria. J. Bacteriol. 175:7658-7665.

He, S. Y., Huang, H. C., and Collmer, A. 1993. Pseudomonas syringae pv. syringae harpin ${ }_{\text {Pss }}$ : A protein that is secreted via the Hrp pathway and elicits the hypersensitive response in plants. Cell 73:1255-1266.

Hessner, M. J., Singh, V. K., Wang, X., Khan, S., Tschannen, M. R., and Zahrt, T. C. 2004. Utilization of a labeled tracking oligonucleotide for visualization and quality control of spotted 70-mer arrays. BMC Genomics 5:12.

Ikai, H., and Yamamoto, S. 1997. Identification and analysis of a gene encoding L-2,4-diaminobutyrate:2-ketoglutarate 4-aminotransferase involved in the 1,3-diaminopropane production pathway in Acinetobacter baumannii. J. Bacteriol. 179:5118-5125.

Jackson, R. W., Athanassopoulos, E., Tsiamis, G., Mansfield, J. W., Sesma, A., Arnold, D. L., Gibbon, M. J., Murillo, J., Taylor, J. D., and Vivian, A. 1999. Identification of a pathogenicity island, which contains genes for virulence and avirulence, on a large native plasmid in the bean pathogen Pseudomonas syringae pathovar phaseolicola. Proc. Natl. Acad. Sci. U.S.A 96:10875-10880.

Joyce, E. A., Kawale, A., Censini, S., Kim, C. C., Covacci, A., and Falkow, S. 2004. LuxS is required for persistent pneumococcal carriage and expression of virulence and biosynthesis genes. Infect. Immun. 72:29642975

Jung, H. C., Park, J. H., Park, S. H., Lebeault, J. M., and Pan, J. G. 1998. Expression of carboxymethylcellulase on the surface of Escherichia coli using Pseudomonas syringae ice nucleation protein. Enzyme Microb. Technol. 22:348-354.

Kane, M. D., Jatkoe, T. A., Stumpf, C. R., Lu, J., Thomas, J. D., and Madore, S. J. 2000. Assessment of the sensitivity and specificity of oligonucleotide (50 mer) microarrays. Nucleic Acids Res. 28:4552-4557.

Kang H., and Gross, D. C. 2003. Characterization of an RND transporter located within the syr-syp genomic island of Pseudomonas syringae pv. syringae. Phytopathology. 93:S43.

Keith, L. M., and Bender, C. L. 1999. AlgT $\left(\sigma^{22}\right)$ controls alginate production and tolerance to environmental stress in Pseudomonas syringae. J. Bacteriol. 181:7176-7184.

Kitten, T., Kinscherf, T. G., McEvoy, J. L., and Willis, D. K. 1998. A newly identified regulator is required for virulence and toxin production in Pseudomonas syringae. Mol. Microbiol. 28:917-929.

Kokjohn, T. A., and Miller, R. V. 1985. Molecular cloning and characterization of the recA gene of Pseudomonas aeruginosa PAO. J. Bacteriol. 163:568-572.

Kuroda, A., Kumano, T., Taguchi, K., Nikata, T., Kato, J., and Ohtake, H. 1995. Molecular cloning and characterization of a chemotactic transducer gene in Pseudomonas aeruginosa. J. Bacteriol. 177:7019-7025.

Laub, M. T., Chen, S. L., Shapiro, L., and McAdams, H. H. 2002. Genes directly controlled by CtrA, a master regulator of the Caulobacter cell cycle. Proc. Natl. Acad. Sci. U.S.A 99:4632-4637.

Li, H., and Ullrich, M. S. 2001. Characterization and mutational analysis of three allelic lsc genes encoding levansucrase in Pseudomonas syringae. J. Bacteriol. 183:3282-3292.

Lidell, M. C., and Hutcheson, S. W. 1994. Characterization of the hrpJ and hrpU operons of Pseudomonas syringae pv. syringae Pss61: Similarity with components of enteric bacteria involved in flagellar biogenesis and demonstration of their role in Harpin ${ }_{\text {Pss }}$ secretion. Mol. Plant-Microbe Interact. 7:488-497.

Lockhart, D. J., Dong, H., Byrne, M. C., Follettie, M. T., Gallo, M. V., Chee, M. S., Mittmann, M., Wang, C., Kobayashi, M., Horton, H., and Brown, E. L. 1996. Expression monitoring by hybridization to highdensity oligonucleotide arrays. Nat. Biotechnol. 14:1675-1680.

Lu, S. E., Scholz-Schroeder, B. K., and Gross, D. C. 2002. Characterization of the $s a l A, s y r F$, and $s y r G$ regulatory genes located at the right border of the syringomycin gene cluster of Pseudomonas syringae pv. syringae. Mol. Plant-Microbe Interact. 15:43-53.

Lu, S. E., Soule, J. D., and Gross, D. C. 2003. Characterization of the $\operatorname{argA}$ gene required for arginine biosynthesis and syringomycin production by Pseudomonas syringae pv. syringae. Appl. Environ. Microbiol. 69:7273-7280

Mahe, B., Masclaux, C., Rauscher, L., Enard, C., and Expert, D. 1995. Differential expression of two siderophore-dependent iron-acquisition pathways in Erwinia chrysanthemi 3937: Characterization of a nove ferrisiderophore permease of the ABC transporter family. Mol. Microbiol. 18:33-43.

Martínez-Antonio, A., and Collado-Vides, J. 2003. Identifying global regulators in transcriptional regulatory networks in bacteria. Curr. Opin. Microbiol. 6:482-489.

Mazzola, M., and White, F. F. 1994. A mutation in the indole-3-acetic acid biosynthesis pathway of Pseudomonas syringae pv. syringae affect 
growth in Phaseolus vulgaris and syringomycin production. J. Bacteriol. 176:1374-1382.

McMorran, B. J., Merriman, M. E., Rombel, I. T., and Lamont, I. L. 1996. Characterisation of the $p v d E$ gene which is required for pyoverdine synthesis in Pseudomonas aeruginosa. Gene 176:55-59.

Miller, C. D., Mortensen, W. S., Braga, G. U., and Anderson, A. J. 2001. The rpoS gene in Pseudomonas syringae is important in surviving exposure to the near-UV in sunlight. Curr. Microbiol. 43:374-377.

Mo, Y. Y., and Gross, D. C. 1991a. Plant signal molecules activate the syrB gene, which is required for syringomycin production by Pseudomonas syringae pv. syringae. J. Bacteriol. 173:5784-5792.

Mo, Y. Y., and Gross, D. C. 1991b. Expression in vitro and during plant pathogenesis of the $\operatorname{syr} B$ gene required for syringomycin production by Pseudomonas syringae pv. syringae. Molecular Plant-Microbe Interact. 4:28-36.

Mootz, H. D., Schwarzer, D., and Marahiel, M. A. 2002. Ways of assembling complex natural products on modular nonribosomal peptide synthetases. Chembiochem 3:490-504.

Mossialos, D., Ochsner, U., Baysse, C., Chablain, P., Pirnay, J. P., Koedam, N., Budzikiewicz, H., Fernández, D. U., Schafer, M., Ravel, J., and Cornelis, P. 2002. Identification of new, conserved, non-ribosomal peptide synthetases from fluorescent pseudomonads involved in the biosynthesis of the siderophore pyoverdine. Mol. Microbiol. 45:1673-1685.

Nelson, K. E., Weinel, C., Paulsen, I. T., Dodson, R. J., Hilbert, H., dos Santos, V. A. P. M., Fouts, D. E., Gill, S. R., Pop, M., Holmes, M., Brinkac, L., Beanan, M., Deboy, R. T., Daugherty, S., Kolonay, J., Madupu, R., Nelson, W., White, O., Peterson, J., Khouri, H., Hance, I., Lee, P. C., Holtzapple, E., Scanlan, D., Tran, K., Moazzez, A., Utterback, T., Rizzo, M., Lee, K., Kosack, D., Moestl, D., Wedler, H., Lauber, J., Stjepandic, D., Hoheisel, J., Straetz, M., Heim, S., Kiewitz, C., Eisen, J., Timmis, K. N., Dusterhöft, A., Tümmler, B., and Fraser, C. M. 2002. Complete genome sequence and comparative analysis of the metabolically versatile Pseudomonas putida KT2440. Environ. Microbiol. 4:799-808.

Okinaka, Y., Yang, C. H., Perna, N. T., and Keen, N. T. 2002. Microarray profiling of Erwinia chrysanthemi 3937 genes that are regulated during plant infection. Mol. Plant-Microbe Interact. 15:619-629.

Price, C. W., Fawcett, P., Cérémonie, H., Su, N., Murphy, C. K., and Youngman, P. 2001. Genome-wide analysis of the general stress response in Bacillus subtilis. Mol. Microbiol. 41:757-774.

Quigley, N. B., and Gross, D. C. 1994. Syringomycin production among strains of Pseudomonas syringae pv. syringae: Conservation of the syrB and $s y r D$ genes and activation of phytotoxin production by plant signal molecules. Mol. Plant-Microbe Interact. 7:78-90.

Quigley, N. B., Mo, Y. Y., and Gross, D. C. 1993. SyrD is required for syringomycin production by Pseudomonas syringae pathovar syringae and is related to a family of ATP-binding secretion proteins. Mol. Microbiol. 9:787-801

Rhodius, V. A., and LaRossa, R. A. 2003. Uses and pitfalls of microarrays for studying transcriptional regulation. Curr. Opin. Microbiol. 6:114119 .

Rich, J. J., Kinscherf, T. G., Kitten, T., and Willis, D. K. 1994. Genetic evidence that the gacA gene encodes the cognate response regulator for the lemA sensor in Pseudomonas syringae. J. Bacteriol. 176:7468-7475.

Richmond, C. S., Glasner, J. D., Mau, R., Jin, H., and Blattner, F. R. 1999. Genome-wide expression profiling in Escherichia coli K-12. Nucleic Acids Res. 27:3821-3835.

Sawada, H., Takeuchi, T., and Matsuda, I. 1997. Comparative analysis of Pseudomonas syringae pv. actinidiae and pv. phaseolicola based on phaseolotoxin-resistant ornithine carbamoyltransferase gene $(\arg K)$ and 16S-23S rRNA intergenic spacer sequences. Appl. Environ. Microbiol. 63:282-288

Schena, M., Shalon, D., Davis, R. W., and Brown, P. O. 1995. Quantitative monitoring of gene expression patterns with a complementary DNA microarray. Science 270:467-470.

Scholz-Schroeder, B. K., Hutchison, M. L., Grgurina, I., and Gross, D. C. 2001a. The contribution of syringopeptin and syringomycin to virulence of Pseudomonas syringae pv. syringae strain B301D on the basis of
sypA and syrB1 biosynthesis mutant analysis. Mol. Plant-Microbe Interact. 14:336-348.

Scholz-Schroeder, B. K., Soule, J. D., and Gross, D. C. 2003. The sypA, sypB and sypC synthetase genes encode twenty-two modules involved in the nonribosomal peptide synthesis of syringopeptin by Pseudomonas syringae pv. syringae B301D. Mol. Plant-Microbe Interact. 16:271280.

Scholz-Schroeder, B. K., Soule, J. D., Lu, S. E., Grgurina, I., and Gross, D. C. 2001b. A physical map of the syringomycin and syringopeptin gene clusters localized to an approximately $145-\mathrm{kb}$ DNA region of Pseudomonas syringae pv. syringae strain B301D. Mol. Plant-Microbe Interact. 14:1426-1435

Schuster, M., Lostroh, C. P., Ogi, T., and Greenberg, E. P. 2003. Identification, timing, and signal specificity of Pseudomonas aeruginosa quorumcontrolled genes: A transcriptome analysis. J. Bacteriol. 185:2066-2079.

Stewart, G. R., Wermisch, L., Stabler, R., Mangan, J. A., Hinds, J., Laing, K. G., Butcher, P. D., and Young, D. B. 2002. The heat shock response of Mycobacterium tuberculosis: Linking gene expression, immunology and pathogenesis. Comp. Funct. Genomics 3:348-351.

Sundin, G. W., Jacobs, J. L., and Murillo, J. 2000. Sequence diversity of rulA among natural isolates of Pseudomonas syringae and effect on function of rulAB-mediated UV radiation tolerance. Appl. Environ. Microbiol. 66:5167-5173.

Tolstrup, N., Nielsen, P. S., Kolberg, J. G., Frankel, A. M., Vissing, H., and Kauppinen, S. 2003. OligoDesign: Optimal design of LNA (locked nucleic acid) oligonucleotide capture probes for gene expression profiling. Nucleic Acids Res. 31:3758-3762.

Wagner, V. E., Bushnell, D., Passador, L., Brooks, A. I., and Iglewski, B. H. 2003. Microarray analysis of Pseudomonas aeruginosa quorumsensing regulons: Effects of growth phase and environment. J. Bacteriol. 185:2080-2095.

Wäspi, U., Blanc, D., Winkler, T., Ruedi, P., and Dudler, R. 1998. Syringolin, a novel peptide elicitor from Pseudomonas syringae pv. syringae that induces resistance to Pyricularia oryzae in rice. Mol. PlantMicrobe Interact. 11:727-733.

Willis, D. K., Hrabak, E. M., Rich, J. J., Barta, T. M., Lindow, S. E., and Panopoulos, N. J. 1990. Isolation and characterization of a Pseudomonas syringae pv. syringae mutant deficient in lesion formation on bean Mol. Plant-Microbe Interact. 3:149-156.

Xiao, Y. X., Heu, S. G., Yi, J. S., Lu, Y., and Hutcheson, S. W. 1994. Identification of a putative alternate sigma factor and characterization of a multicomponent regulatory cascade controlling the expression of $\mathrm{Pseu}$ domonas syringae pv. syringae PSS61 hrp and hrmA genes. J. Bacteriol. 176:1025-1036.

Young, J. M. 1991. Pathogenicity and identification of the lilac pathogen, Pseudomonas syringae pv. syringae Van Hall 1902. Ann. Appl. Biol. 118:283-298.

Zhang, J. H., Quigley, N. B., and Gross, D. C. 1995. Analysis of the syrB and $\operatorname{syrC}$ genes of Pseudomonas syringae pv. syringae indicates that syringomycin is synthesized by a thiotemplate mechanism. J. Bacteriol. 177:4009-4020.

Zhang, J. H., Quigley, N. B., and Gross, D. C. 1997. Analysis of the syrP gene, which regulates syringomycin synthesis by Pseudomonas syringae pv. syringae. Appl. Environ. Microbiol. 63:2771-2778.

Zheng, M., Wang, X., Templeton, L. J., Smulski, D. R., LaRossa, R. A., and Storz, G. 2001. DNA microarray-mediated transcriptional profiling of the Escherichia coli response to hydrogen peroxide. J. Bacteriol. 183:4562-4570.

\section{AUTHOR RECOMMENDED INTERNET RESOURCES}

Joint Genome Institute (JGI) and United States Department of Energy (DOE) homepage: www.jgi.doe.gov

JGI-DOE Pseudomonas syringae pv. syringae B728a genome sequence project: genome.jgi-psf.org/draft_microbes/psesy/psesy.home.html JGI-DOE microbial index site: www.jgi.doe.gov/JGI_microbial

Qiagen website: www.qiagen.com

Agilent Technologies website: www.chem.agilent.com 